\title{
LIGHT TWO-WHEELED ELECTRIC VEHICLE ENERGY BALANCE INVESTIGATION USING CHASSIS DYNAMOMETER
}

\author{
Szymon RACEWICZ, ${ }^{*}$ Paweł KAZIMIERCZUK*
}

${ }^{*}$ Faculty of Technical Sciences, Department of Mechatronics and Technical-Computer Sciences Education,
University of Warmia and Mazury in Olsztyn, 2 Michała Oczapowskiego St., 10-719 Olsztyn, Poland
${ }^{*}$ Maintenance Department, Michelin Polska S.A., 9 Władysława Leonharda St., 10-454 Olsztyn, Poland

szymon.racewicz@uwm.edu.pl, pawel.kazimierczuk@michelin.com

received 30 April 2020, revised 15 January 2021, accepted 19 January 2021

\begin{abstract}
The article presents the methodology for light two-wheeled electric vehicle energy balance investigation using MAHA LPS 3000 chassis dynamometer. For this purpose, the laboratory tests, as well as the road tests, have been performed on the self-constructed light two-wheeled electric vehicle equipped with the $3 \mathrm{~kW} \mathrm{BLDC}$ motor and the $100.8 \mathrm{~V}$ battery pack. The road test data have been used to set up the dynamometer parameters in order to simulate the real road drive taking into account, among others, the rolling resistances and the air drag coefficient. The overall energy consumption for the laboratory tests and the road conditions' tests have been then compared for different vehicle speeds. In addition, based on the power and the torque characteristics measured on the MAHA chassis dynamometer, the efficiency of the vehicle electric drive system and the efficiency of the battery charging process have been calculated.
\end{abstract}

Keywords: Electric vehicle, energy balance, chassis dynamometer, drive system efficiency

\section{INTRODUCTION}

Since the last few decades, electric vehicles have gained in popularity. This is because of the recent technological improvements in the areas of electric motors, power electronics, and energy storages, which makes them more accessible and affordable (Ho et al., 2014; Lin et al., 2015; Lim et al., 2016; Sarlioglu et al., 2017; Li et al., 2018). Other reasons are the obvious environmental advantages and the much lower cost of transportation in comparison to the vehicles with internal combustion engines or even hybrids (Bertoluzzo and Buja, 2011; Saponara et al., 2020). Although this cost is relatively low, it is still closely related to the overall efficiency of the electric vehicle drive system and so it can be further reduced. This is an issue raised in many researches, for example, Kumar et al. (2017), Kumar and Sivakumar (2017), Laitinen et al. (2017), Dobrucky et al. (2019) and Zaghari et al. 2020). In order to better investigate and implement new technical solutions, one has to provide repetitive traction conditions during certain tests. Chassis dynamometers help to study motor parameters as well as the fuel or energy consumption in laboratory conditions (Chen Mingjie et al., 2010). Nevertheless, most chassis dynamometers, for example, the MAHA LPS 3000, are originally dedicated to power characteristics investigation of cars and motorcycles. Their predefined parameter sets mainly apply to vehicles with internal combustion engines. The MAHA dynamometer can simulate the real road conditions using the eddy current breaks. Moreover, it can also measure the characteristics of fourwheel-drive vehicles. It is then interesting to use such a dynamometer for light two-wheeled electric vehicle testing in order to investigate its mechanical and electrical parameters.

\section{LIGHT TWO-WHEELED ELECTRIC VEHICLE CONSTRUCTION}

The studied vehicle has been designed and built from scratch using brushless DC motor of $3 \mathrm{~kW}$ of nominal continuous output mechanical power and the battery pack built of 360 lithium-ion power cells of $2600 \mathrm{mAh}$ each. According to the Polish law formulated in the Act on Road Traffic of June 20, 1997, with the changes made on April 1, 2011, it cannot be called electric bicycle, neither electric moped among others due to the over normed output power (UPRD (1997), 1997). Indeed, the vehicle weighs $78 \mathrm{~kg}$ and can reach the speed of up to about $100 \mathrm{~km} / \mathrm{h}$. The maximum output power measured on the chassis dynamometer has been equal to $4.7 \mathrm{~kW}(6.4 \mathrm{BHP})$ with $184.1 \mathrm{Nm}$ of torque for $440 \mathrm{rpm}$. The motor is placed in the rear wheel hub without any gearbox. The maximum voltage of the battery pack is $100.8 \mathrm{~V}$ with the $39 \mathrm{Ah}$ of nominal capacity. More detailed information about the previous prototype of the vehicle can be found in Racewicz et al. (2018). Its final version is presented in Fig. 1.

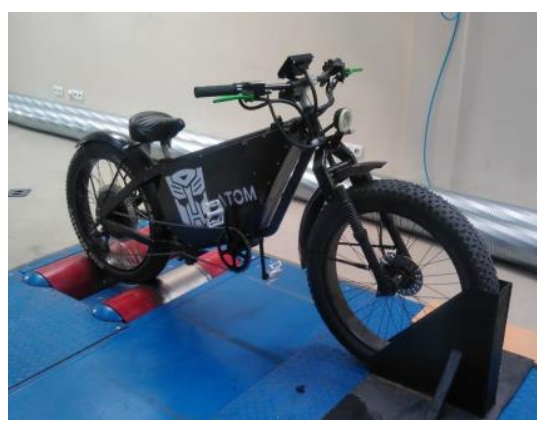

Fig. 1. Light two-wheeled electric vehicle powered by $3 \mathrm{~kW}$ BLDC motor and classical bicycle pedals 


\section{DESCRIPTION OF TESTS}

In order to find coherence between vehicle electric parameters recorded during real road drive and the simulated road drive on the MAHA LPS 3000 chassis dynamometer, several assumptions have to be met. These are the recommendations of the dynamometer manufacturer as well as the official procedures described in COMMISSION DELEGATED REGULATION (EU) No 134/2014 of 16 December 2013 supplementing Regulation (EU) No 168/2013 of the European Parliament and of the Council with regard to environmental and propulsion unit performance requirements and amending Annex V the (2013).

All the tests were carried out with a fully charged battery when the ambient temperature was about $24^{\circ} \mathrm{C}$. The test road was sufficiently long and straight without any inclinations. Wind speed was close to zero. The measurements started at a speed of 10 $\mathrm{km} / \mathrm{h}$, which was then increased by $10 \mathrm{~km} / \mathrm{h}$ until it reached the speed of $90 \mathrm{~km} / \mathrm{h}$. The speed was controlled using the vehicle speedometer. For each speed, the time, distance, motor voltage, motor current and power were registered and saved on the SD card by the on-board computer designed for this purpose. The measurements of electric parameters were recorded in $0.5 \mathrm{~s}$ intervals and were then averaged for calculations. The summarized road measurements results are presented in Tab. 1.

Tab. 1. Road tests results

\begin{tabular}{|c|c|c|c|c|}
\hline $\begin{array}{c}\text { Speed } \\
{[\mathbf{k m} / \mathbf{h}]}\end{array}$ & $\begin{array}{c}\text { Time } \\
{[\mathbf{s}]}\end{array}$ & $\begin{array}{c}\text { Distance } \\
{[\mathrm{m}]}\end{array}$ & $\begin{array}{c}\text { Current } \\
{[\mathrm{A}]}\end{array}$ & $\begin{array}{c}\text { Power } \\
{[\mathbf{k W}]}\end{array}$ \\
\hline 10.00 & 60.35 & 169.70 & 0.96 & 0.10 \\
\hline 20.00 & 25.50 & 141.67 & 2.08 & 0.21 \\
\hline 30.00 & 25.50 & 212.50 & 4.24 & 0.41 \\
\hline 40.00 & 25.25 & 280.56 & 5.86 & 0.58 \\
\hline 50.00 & 18.50 & 256.94 & 11.00 & 1.07 \\
\hline 60.00 & 22.00 & 366.67 & 20.39 & 1.96 \\
\hline 70.00 & 20.50 & 398.61 & 29.42 & 2.79 \\
\hline 80.00 & 18.25 & 405.56 & 42.06 & 3.91 \\
\hline 90.00 & 21.25 & 531.25 & 64.21 & 5.81 \\
\hline
\end{tabular}

The same procedure was repeated on the chassis dynamometer for the laboratory tests. Drive profile representing the actual speed of the vehicle and its motor current is shown in Fig. 2 and the measurement values are collected in Tab. 2 .

Tab. 2. Laboratory tests results

\begin{tabular}{|c|c|c|c|c|}
\hline $\begin{array}{c}\text { Speed } \\
{[\mathrm{km} / \mathrm{h}]}\end{array}$ & $\begin{array}{c}\text { Time } \\
{[\mathbf{s}]}\end{array}$ & $\begin{array}{c}\text { Distance } \\
{[\mathrm{m}]}\end{array}$ & $\begin{array}{c}\text { Current } \\
{[\mathbf{A}]}\end{array}$ & $\begin{array}{c}\text { Power } \\
{[\mathrm{kW}]}\end{array}$ \\
\hline 10.00 & 24 & 67 & 3.29 & 0.33 \\
\hline 20.00 & 13 & 69 & 7.07 & 0.71 \\
\hline 30.00 & 16 & 126 & 10.22 & 1.02 \\
\hline 40.00 & 13 & 140 & 14.46 & 1.43 \\
\hline 50.00 & 19 & 264 & 18.57 & 1.83 \\
\hline 60.00 & 17 & 275 & 24.58 & 2.39 \\
\hline 70.00 & 16 & 300 & 26.90 & 2.55 \\
\hline 80.00 & 19 & 417 & 32.31 & 3.10 \\
\hline 90.00 & 14 & 346 & 43.29 & 4.12 \\
\hline 100.00 & 14 & 385 & 47.06 & 4.40 \\
\hline
\end{tabular}

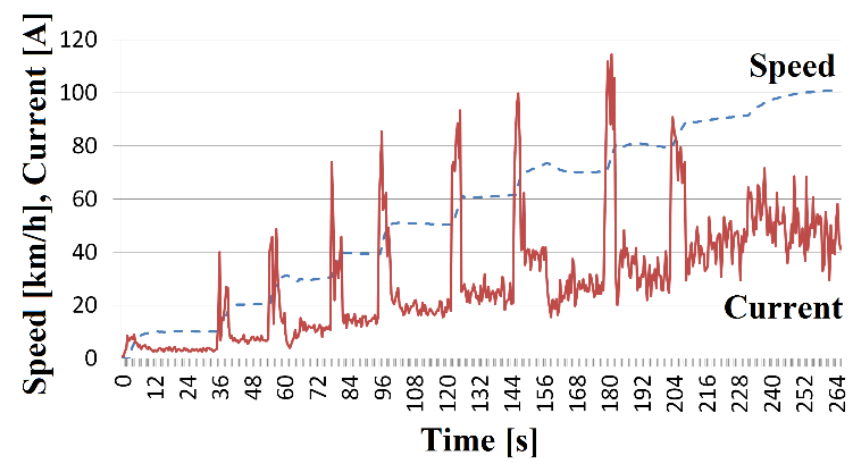

Fig. 2. Speed and motor current registered during chassis dynamometer test

In order to set up the MAHA chassis dynamometer parameters, the data collected during the road test, that is, speed, motor voltage and current were mapped for a laboratory test. The ambient temperature in the laboratory room was about $22^{\circ} \mathrm{C}$. The MAHA LPS 3000 chassis dynamometer enables exact simulation of the predefined real road drive conditions. The load is applied by the eddy current brakes as a function of vehicle speed, which reflects different road drive conditions. This process is supervised by the microprocessor-controlled computing unit with graphic and digital display of the measured values.

For the test purpose, the MAHA chassis dynamometer parameters were set up assuming that the vehicle is moving linearly on the flat horizontal surface. The total driving force $F$ on the rear wheel is determined by relation (1) and the power $P$ on the wheel is described by equation (2):

$F=F_{\mathrm{r}}+F_{\mathrm{w}}+F_{\mathrm{g}}+F_{\mathrm{b}}=$

$m \cdot g \cdot f+0,5 \rho \cdot C_{\mathrm{D}} \cdot A_{\mathrm{f}} \cdot v^{2}+m \cdot g \cdot w+m \cdot a$

$P=F \cdot v$

where $v$ is the speed of the vehicle, $a$ is the acceleration of the vehicle, $m=123 \mathrm{~kg}$ is the mass of the vehicle with driver, $g=9.81 \mathrm{~m} / \mathrm{s}^{2}$ is the gravity acceleration, $f=0.009$ is the rolling resistance coefficient, $\rho=1.2 \mathrm{~kg} / \mathrm{m}^{3}$ is the air density, $C_{D}=0.5$ is the air drag coefficient, $A_{\mathrm{f}}=0.62 \mathrm{~m}^{2}$ is the frontal area taking into account the driver posture, $w$ is the road inclination. The more detailed procedure of setting up the MAHA chassis dynamometer and determining all the needed components concerning driving forces and vehicle coefficients have been described in Kolator et al. (2018).

\section{ENERGY CONSUMPTION ANALYSIS}

Using data from the road tests (Tab. 1) as well as the laboratory tests (Tab. 2), the energy consumption $E$ for each speed was evaluated and compared. For calculations of the energy consumption, formula (3) has been applied.

$E=\frac{P \cdot t}{s} \cdot \frac{2500}{9}$

where $E$ is the consumed energy in [Wh/km], $P$ is the motor power in [kW], $t$ is the drive time in [s] and $s$ is the distance travelled in $[\mathrm{m}]$.

Fig. 3 presents the comparison between energy consumption during road and laboratory tests for different speeds. 


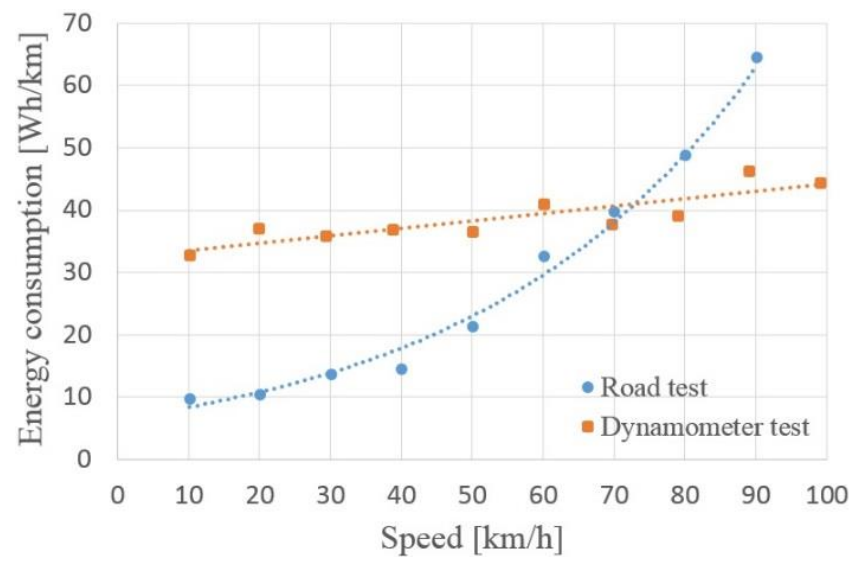

Fig. 3. Comparison of energy consumption during road and laboratory tests

The discrepancy of the energy consumption results for the road and laboratory tests especially for low speeds is due to the fact that the dynamometer rollers and eddy current brakes have an important inertia factor, which cannot be lowered. Moreover, the eddy current brakes are cooled by the fans placed on the same shaft as rollers, which introduces an additional load proportional to the roller speed. Analysing Fig. 3, one can observe that in the light two-wheeled vehicle case, the chassis dynamometer can be successfully used and controlled over the speed of about 70 $\mathrm{km} / \mathrm{h}$. Moreover, different natures of the characteristics, that is, quadratic for the road tests and linear for the laboratory tests are due to the lack of air resistance in laboratory conditions, which was simulated by the changing load of the chassis dynamometer rollers. Nevertheless, for such small values of the vehicle parameters introduced to the chassis dynamometer computer, it generated the rollers' load close to zero, so just the linear load coming from the rollers' fans was applied. This is the main limit of car chassis dynamometers, which has to be taken into account for such type of measurements.

Battery pack capacity has also an impact on the total energy consumption of the electric vehicle (Fei Feng et al., 2012; Park et al., 2019). A properly designed battery pack maximizes the use of energy resources in relation to the distance travelled. In order to properly design the battery pack, one has to take into consideration the following important aspects: maximum discharge current, single cell capacity, total battery weight and mass distribution over the battery volume. Available battery cells can be divided into two categories: low current cells with high capacity and high current cells with low capacity. For low power vehicles (up to $3 \mathrm{~kW}$ ), the better solution is to use high capacity cells. The advantage of such a configuration is the lower weight of the battery pack and its higher energy storage capacity. This results in larger distances, which can be covered by a vehicle. The disadvantage of such a solution is faster cells' wear, which is about 3 years assuming daily use of a vehicle. The second group are the high current low capacity cells, which can deliver higher current translated into better driving dynamics but also higher operating temperature. This solution obliges to design larger and heavier battery packs in order to obtain a similar capacity as for the high capacity cells. The advantage of using a high discharge current cells is the longer battery life, which is about several years assuming the same conditions as mentioned above. The batteries used in the studied project are the high current low capacity Li-ion cells SONY US18650VTC5. The total weight of the battery pack is about 18 $\mathrm{kg}$.
During the laboratory tests on the chassis dynamometer, the weight of the vehicle is not taken into account as the vehicle is tested in a stable position. The MAHA chassis dynamometer is able to simulate an inertial force for the vehicles whose mass exceeds $200 \mathrm{~kg}$. However, the usefulness of such an approach has been proved for the lithium-ion electric vehicle battery parameter estimation in Kim et al. (2016). In the next section, an approach for the overall efficiency of the electric drive system has been proposed. In contrast to the energy consumption analysis, it gives the unequivocal results, which are independent of the assumed road conditions.

\section{EFFICIENCY OF THE ELECTRIC DRIVE SYSTEM}

In order to evaluate the efficiency of the vehicle electric drive system, the power and torque characteristics' test was carried out using the MAHA chassis dynamometer. Discrete measurement option was used. The measurement started at a speed of $20 \mathrm{~km} / \mathrm{h}$, which was then increased by $10 \mathrm{~km} / \mathrm{h}$ until it reached a speed of $80 \mathrm{~km} / \mathrm{h}$. The results from the MAHA computer system are presented in Fig. 4.

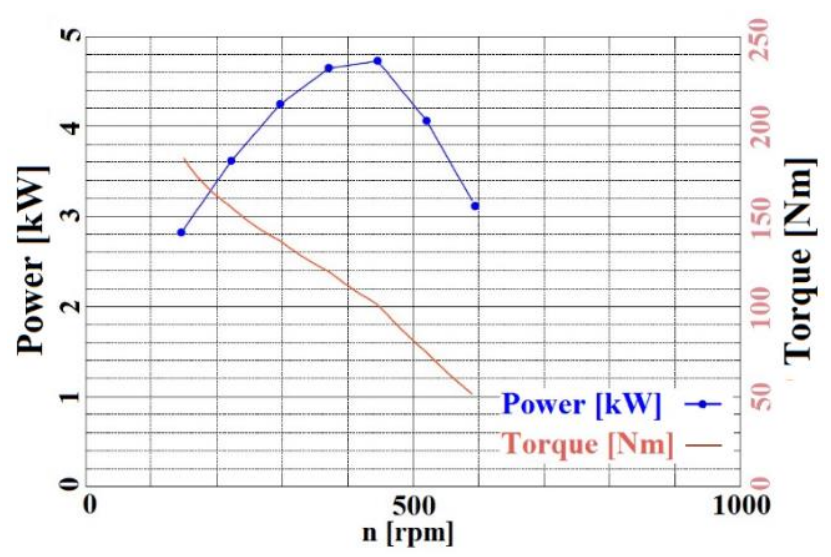

Fig. 4. Power and torque characteristics of the light two-wheeled electric vehicle

During the test, the voltage of the battery pack as well as the total current consumed by the vehicle were measured and stored in the on-board data acquisition system based on Arduino Mega 2560 Pro platform. In the studied case, the use of such simple DAQ system gives reliable measurement results (Barański et al., 2019). In addition to the voltage and current measurements, the system also displayed the actual calculated power consumed by the vehicle, the actual speed, percentage of the battery charge as well as the temperatures of the BLDC motor, motor controller and the battery pack, which is extremely important for the battery pack operation and its life cycle (Chu et al., 2011). The on-board computer consumes about $200 \mathrm{~W}$ of power, which is not a relevant value in comparison to the BLDC motor power and so it was neglected in the further considerations. The averaged measured values of the voltage and current for the maximum mechanical power were equal to respectively $97.2 \mathrm{~V}$ and $111.28 \mathrm{~A}$.

The maximum mechanical power obtained during the test was equal to $4.7 \mathrm{~kW}(6.4 \mathrm{BHP})$ for $440 \mathrm{rpm}$ and the maximum torque was equal to $184.1 \mathrm{Nm}$. For total drive system efficiency calculations, formula (4) has been used. 
$\mu=\frac{P_{\text {mechanical }}}{P_{\text {electrical }}} \cdot 100 \%$

where $P_{\text {mechanical }}$ is the mechanical power measured using the chassis dynamometer and $P_{\text {electrical }}$ is the electrical power calculated as a product of consumed voltage and current measured on the battery pack output, that is, $10.82 \mathrm{~kW}$. The final efficiency value of the studied electric vehicle drive system was estimated as $43.44 \%$. This is a typical value for such constructions based on the powerful BLDC motors and the high voltage battery packs.

Fig. 5 shows the heat losses in the BLDC motor during intensive vehicle exploitation which have an important impact on the total electric drive system efficiency. Moreover, similar losses are present in the motor controller which is placed on the top side of the battery compartment near the vehicle saddle (Fig. 6). It should be noted that the original motor has undergone some technical modifications to increase its operating temperature range. These are, firstly, replacement of $4 \mathrm{~mm}^{2}$ power cables to $8 \mathrm{~mm}^{2}$, which resulted in heat losses reduction, and hence, increased power transmitted to the motor. Secondly, replacement of the original motor windings to the ones with a thicker insulation, that is, two layers of polyurethane varnish and an external coating of polyamide varnish. Thirdly, the two small fans were installed inside the motor to create air circulation. Fourth, the aluminium heat sink was mounted on the motor housing for better heat dissipation. The actual temperature inside the motor is provided by the PT100 sensor, which transmits this information to the controller.

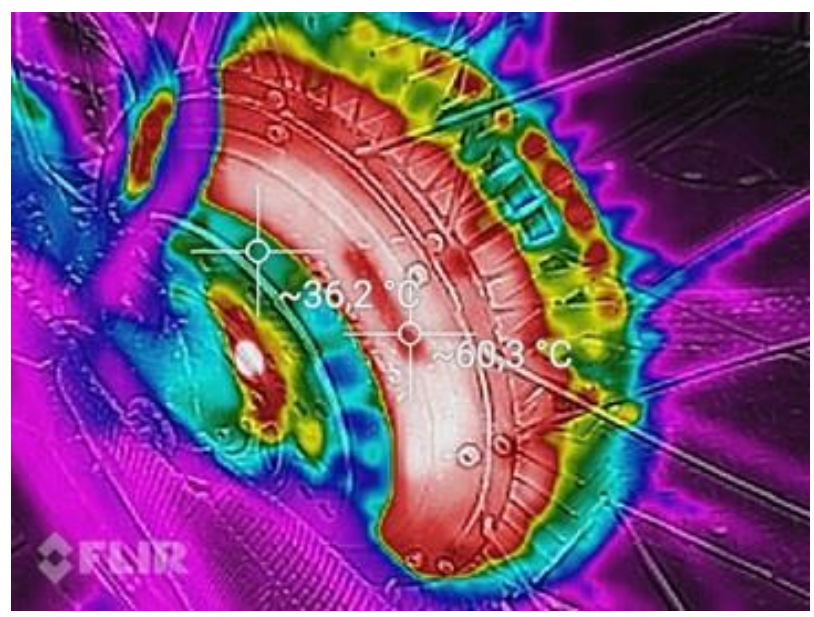

Fig. 5. Temperature of the BLDC motor during chassis dynamometer tests

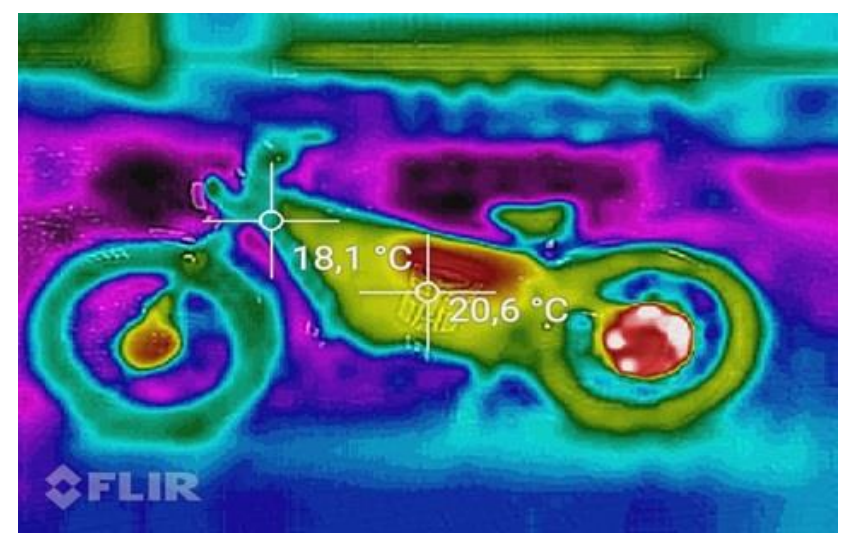

Fig. 6. Distribution of heat losses in the light two-wheeled electric vehicle
Thanks to these modification, the motor operating temperature range increased from $150^{\circ} \mathrm{C}$ to about $200^{\circ} \mathrm{C}$ and the operating voltage increased to about $240 \mathrm{~V}$. Nevertheless, due to security reasons, the motor controller was programmed to maintain the motor temperature below $120^{\circ} \mathrm{C}$. Exceeding this temperature results in a noticeable power reduction, which has to be controlled during the tests.

Apart from the heat losses present in the vehicle drive system, one has to take into account the losses associated with the power transmission between the vehicle and the chassis dynamometer. In order to avoid a drive wheel slipping on the rollers, the vehicle must be tightly pressed against the rollers, which introduces additional tire deflection losses.

\section{ELECTRIC VEHICLE CHARGING BALANCE}

Charging of the electric vehicle batteries is also a process that consumes some additional amount of energy (Khan and Choi, 2018; Ahn and Lee, 2019). In order to measure an efficiency of charging process, the battery pack was discharged to $84.85 \mathrm{~V}$, which is the $84.18 \%$ of its maximum voltage. The nominal capacity of the SONY VTC5 cell is $2600 \mathrm{mAh}$, but in reality, this value oscillates around $2560 \mathrm{mAh}$ when the cell is new. The cut-off voltage of this cell is $2 \mathrm{~V}$, which is interpreted as $0 \%$ of charge. Nevertheless, frequent discharging to such a voltage leads to an irreversible damage of the cell. In practice, the cell loses its operating properties at about $2.5 \mathrm{~V}$ and a significant loss of its capacity is already observed at a voltage of about $3.3 \mathrm{~V}$ (Test of Sony US18650VTC5 2600mAh (Green)). Therefore, devices such as BMS (Battery Management System) and on-board computer system were programmed to control the voltage to a minimum limit of $3.5 \mathrm{~V}$ to maintain the maximum battery life.

Tab. 3. Charging test results

\begin{tabular}{|c|c|c|}
\hline Parameter & Device 1 & Device 2 \\
\hline Voltage before charging & \multicolumn{2}{|c|}{$84.85 \mathrm{~V}$} \\
\hline Voltage after charging & \multicolumn{2}{|c|}{$100.8 \mathrm{~V}$} \\
\hline $\begin{array}{c}\text { Charging energy/ } \\
\text { battery capacity }\end{array}$ & $2.64 \mathrm{kWh} / 28.9 \mathrm{Ah}$ & $2.92 \mathrm{kWh} / 29.2 \mathrm{Ah}$ \\
\hline
\end{tabular}

For the charging test, two devices were used. The first (Device 1) was plugged in between the battery charging socket and the vehicle charger output while the second (Device 2) was plugged in directly to the power socket and the vehicle charger input. The battery charging time was 8 hours and 38 minutes and cost about $€ 0.41$. Tab. 3 summarizes values measured during the test. One has to notice that the real capacity of the battery pack decreased significantly from nominal 39 Ah to about $29 \mathrm{Ah}$, which is a result of natural cells ageing used intensively for more than 2 years. Considering the data from the Tab. 3 , the charging efficiency was estimated at $90 \%$.

\section{CONCLUSIONS}

Responding to an increased interest in electric vehicles design and operation, the authors have proposed the procedures for light two-wheeled electric vehicle energy balance investigation using a 
car chassis dynamometer. These are: the energy consumption analysis, the overall efficiency test of the electric drive system and the electric vehicle charging balance studies. Regarding the first of above mentioned procedures one can conclude that the use of the car chassis dynamometer allows to investigate the energy consumption only for some range of speeds. This issue is closely related to the studied vehicle performances, that is, the more powerful the vehicle is, the better coherence of the analysis can be obtained. On the other hand, during efficiency test of light vehicle electric drive system, the excessive power can cause the wheel to slide on the dynamometer rollers, which distorts the results. The vehicle should be firmly attached to the test stand and the additional tire deflection losses should be taken into consideration.

Being conscious about the inconveniences and limits of the car chassis dynamometer (i.e., important rollers inertia factor) for light electric vehicles testing as well as about the advantages of such approach, one can prepare valuable testing procedures.

\section{REFERENCES}

1. Ahn J.-H., Lee B.K. (2019) High-Efficiency Adaptive-Current Charging Strategy for Electric Vehicles Considering Variation of Internal Resistance of Lithium-Ion Battery, IEEE Transactions on Power Electronics, 34(4), 3041-3052.

2. Barański R., Galewski M., Nitkiewicz S. (2019) The study of Arduino Uno feasibility for DAQ purposes, Diagnostyka, 20(2), 33-48.

3. Bertoluzzo M., Buja G. (2011) Development of Electric Propulsion Systems for Light Electric Vehicles, IEEE Transactions on Industrial Informatics, 7(3), 428-435.

4. Chen M., Jin Z.a, Lu Q., Ye X., Fang M., Qin K. (2010) A chassis dynamometer laboratory for fuel cell hybrid vehicles and the hydrogen consumption measurement system, in 2010 IEEE Vehicle Power and Propulsion Conference. IEEE, 1-5.

5. Chu L., Zhou F., Guo J. (2011) Investigation of cycle life of li-ion power battery pack based on LV-SVM, in 2011 International Conference on Mechatronic Science, Electric Engineering and Computer (MEC). IEEE, 1602-1605.

6. Commission Delegated Regulation (EU) No 134/2014 of 16 December 2013 supplementing Regulation (EU) No 168/2013 of the European Parliament and of the Council with regard to environmental and propulsion unit performance requirements and amending Annex $\checkmark$ the (2013).

7. Dobrucky B., Kascak S., Prazenica M., Jarabicova M. (2019) Improving Efficiency of Hybrid Electric Vehicle Using Matrix Converters, Elektronika ir Elektrotechnika, 25(4), 29-35.

8. Fei F., Rengui L., Guoliang W., Chunbo Z. (2012) A measuring method of available capacity of Li-lon series battery pack, in 2012 IEEE Vehicle Power and Propulsion Conference, IEEE, 389-394.

9. Ho T.Y., Chen W. C., Chiang C. H., Hung W. C., Chen M. S. (2014) The Design of Motor Drive with Speed Control for an Electric Bicycle, in 2014 International Symposium on Computer, Consumer and Control. IEEE, 864-867.

10. Khan A.B., Choi W. (2018) Optimal Charge Pattern for the HighPerformance Multistage Constant Current Charge Method for the LiIon Batteries, IEEE Transactions on Energy Conversion, 33(3), $1132-1140$.

11. Kim N., Rousseau A., Rask E. (2016) Parameter Estimation for a Lithium-Ion Battery From Chassis Dynamometer Tests, IEEE Transactions on Vehicular Technology, 65(6), 4393-4400.

12. Kolator B., Racewicz S., Olszewski A. (2018) Bench tests results of the traction parameters of the light two-wheeled electric vehicle, IOP Conference Series: Materials Science and Engineering, 421(2), 022015 .
13. Kumar B.V.R., Sivakumar K. (2017) Design of a new switchedstator BLDC drive to improve the energy efficiency of an electric vehicle, in 2017 IEEE International Conference on Industrial Technology (ICIT). IEEE, 532-537.

14. Kumar B. V. R., Sivakumar K., Karunanidhi S. (2017) A novel configuration of regenerative braking system to improve the energy efficiency of an electric vehicle with Dual-Stator Dual-Rotor BLDC motor, in 2017 IEEE Transportation Electrification Conference (ITECIndia), IEEE, 1-4.

15. Laitinen H., Lajunen A., Tammi K. (2017) Improving Electric Vehicle Energy Efficiency with Two-Speed Gearbox, in 2017 IEEE Vehicle Power and Propulsion Conference (VPPC), IEEE, 1-5.

16. Li Y., Hu J., Chen F., Liu S., Yan Z., He Z. (2018) A New-VariableCoil-Structure-Based IPT System With Load-Independent Constant Output Current or Voltage for Charging Electric Bicycles, IEEE Transactions on Power Electronics, 33(10), 8226-8230..

17. Lim D.-K., Cho Y.-S., Ro J.-S., Jung S.-Y., Jung H.-K. (2016) Optimal Design of an Axial Flux Permanent Magnet Synchronous Motor for the Electric Bicycle, IEEE Transactions on Magnetics, 52(3), 1-4.

18. Lin J., Schofield N., Emadi A. (2015) External-Rotor 6-10 Switched Reluctance Motor for an Electric Bicycle, IEEE Transactions on Transportation Electrification, 1(4), 348-356.

19. Park M., Seo M., Song Y., Kim S. (2019) Capacity Estimation of Liion battery using Constant Current Charging Voltage, in 2019 IEEE Asia Pacific Conference on Circuits and Systems (APCCAS). IEEE, 202-204.

20. Racewicz S., Kazimierczuk P., Kolator B., Olszewski A. (2018) Use of $3 \mathrm{~kW}$ BLDC motor for light two-wheeled electric vehicle construction, IOP Conference Series: Materials Science and Engineering, 421(4), 042067.

21. Saponara S., Lee C. H. T., Wang N. X., Kirtley J. L. (2020) Electric Drives and Power Chargers: Recent Solutions to Improve Performance and Energy Efficiency for Hybrid and Fully Electric Vehicles, IEEE Vehicular Technology Magazine, 15(1), 73-83.

22. Sarlioglu B., Morris C. T., Han D., Li S. (2017) Driving Toward Accessibility: A Review of Technological Improvements for Electric Machines, Power Electronics, and Batteries for Electric and Hybrid Vehicles, IEEE Industry Applications Magazine, 23(1), 14-25.

23. Test of Sony US18650VTC5 $2600 \mathrm{mAh}$ (Green) (no date). Available at: https://lygte-info.dk/review/batteries2012/Sony US18650VTC5 2600mAh \%28Green\%29 UK.html (Accessed: 30 December 2019).

24. UPRD (1997) Act of June 20, 1997, Road Traffic Law, Journal of Laws, (in Polish), 3113.

Available at:

http://prawo.sejm.gov.pl/isap.nsf/download.xsp/WDU19970980602/U /D19970602Lj.pdf (Accessed: 25 April 2018).

25. Zaghari B., Stuikys A., Weddell A. S., Beeby S. (2020) Efficient Energy Conversion in Electrically Assisted Bicycles Using a Switched Reluctance Machine Under Torque Control, IEEE Access, 8, 202401-202411. d

We would like to thank Prof. Bronisław Kolator and Dr Jarosław Gonera from the Department of Construction, Operation of Vehicles and Machines of the University of Warmia and Mazury in Olsztyn for their assistance and help during chassis dynamometer tests. 